\title{
Use of Uranyl Peroxide Precipitation as a Means to Clean up Irradiated Uranyl Sulfate Target Solutions
}

Chemical Science and Engineering Division 


\begin{abstract}
About Argonne National Laboratory
Argonne is a U.S. Department of Energy laboratory managed by UChicago Argonne, LLC under contract DE-AC02-06CH11357. The Laboratory's main facility is outside Chicago, at 9700 South Cass Avenue, Argonne, Illinois 60439. For information about Argonne and its pioneering science and technology programs, see www.anl.gov.
\end{abstract}

\title{
DOCUMENT AVAILABILITY
}

Online Access: U.S. Department of Energy (DOE) reports produced after 1991 and a growing number of pre-1991 documents are available free via DOE's SciTech Connect (http://www.osti.gov/scitech/)

Reports not in digital format may be purchased by the public from the National Technical Information Service (NTIS):

U.S. Department of Commerce

National Technical Information Service

5301 Shawnee Rd

Alexandra, VA 22312

www.ntis.gov

Phone: (800) 553-NTIS (6847) or (703) 605-6000

Fax: (703) 605-6900

Email: orders@ntis.gov

Reports not in digital format are available to DOE and DOE contractors from the Office of Scientific and Technical Information (OSTI):

U.S. Department of Energy

Office of Scientific and Technical Information

P.O. Box 62

Oak Ridge, TN 37831-0062

www.osti.gov

Phone: (865) 576-8401

Fax: (865) 576-5728

Email: reports@osti.gov

\footnotetext{
Disclaimer

This report was prepared as an account of work sponsored by an agency of the United States Government. Neither the United States Government nor any agency thereof, nor UChicago Argonne, LLC, nor any of their employees or officers, makes any warranty, express or implied, or assumes any legal liability or responsibility for the accuracy, completeness, or usefulness of any information, apparatus, product, or process disclosed, or represents that its use would not infringe privately owned rights. Reference herein to any specific commercial product, process, or service by trade name, trademark, manufacturer, or otherwise, does not necessarily constitute or imply its endorsement, recommendation, or favoring by the United States Government or any agency thereof. The views and opinions of document authors expressed herein do not necessarily state or reflect those of the United States Government or any agency thereof, Argonne National Laboratory, or UChicago Argonne, LLC.
} 


\section{Use of Uranyl Peroxide Precipitation as a Means to Clean up Irradiated Uranyl Sulfate Target Solutions}

by

Delbert Bowers and George F. Vandegrift

Chemical Science and Engineering Division, Argonne National Laboratory

prepared for

U.S. Department of Energy, National Nuclear Security Administration,

Office of Defense Nuclear Nonproliferation

February 28, 2012 



\section{USE OF URANYL PEROXIDE PRECIPITATION AS A MEANS TO CLEAN UP IRRADIATED URANYL SULFATE TARGET SOLUTIONS}

Several methods were considered by Argonne National Laboratory (Argonne) for periodic cleanup of the irradiated uranyl sulfate SHINE target solutions. These methods included (1) conversion to nitrate media followed by UREX processing, (2) direct solvent-extraction process for uranyl sulfate, (3) anion exchange of uranyl sulfate complexes, and (4) precipitation of uranyl ion as uranyl peroxide. A final version of a report discussing these four options was sent to Morgridge Institute for Research (MIR) on August 10, 2011. The report was based on both literature and Argonne experimental data. It concluded that only two of the four options, options 1 and 4, had any chance of success.

The most developed and straightforward method was option 1; however, Argonne was asked to perform further experiments on the uranyl-peroxide precipitation method to see to see whether its flaws could be overcome.

In principal, the precipitation should be straightforward; the solubility product $\left(\mathrm{K}_{\mathrm{sp}}=\left[\mathrm{UO}_{2}{ }^{2+}\right] \times\left[\mathrm{O}_{2}{ }^{2-}\right]\right)$ for uranyl peroxide is $1.3 \times 10^{-36}$ (Djogic et al. 2005). However, there are many factors that influence the concentrations of free $\mathrm{UO}_{2}{ }^{2+}$ ions and free $\mathrm{O}_{2}{ }^{2-}$ ions, and therefore the completeness of the precipitation. For uranyl ions, there are $\mathrm{pH}$-dependent hydrolysis reactions that form the species $\mathrm{UO}_{2} \mathrm{OH}^{1+}, \mathrm{UO}_{2}(\mathrm{OH})_{2}$, and $\mathrm{UO}_{2}(\mathrm{OH})_{3}{ }^{1-}$, as well as sulfate complexes $\mathrm{UO}_{2} \mathrm{SO}_{4}, \mathrm{UO}_{2}\left(\mathrm{SO}_{4}\right)_{2}{ }^{2-}$, and $\mathrm{UO}_{2}\left(\mathrm{SO}_{4}\right)_{3}{ }^{4-}$. The free peroxide-ion concentration is also affected by the $\mathrm{pH}$, due to formation of the weak acids $\mathrm{H}_{2} \mathrm{O}_{2}$ and $\mathrm{HO}_{2}{ }^{-}$. The relative concentrations of uranyl-sulfate complexes are also related to $\mathrm{pH}$ through the equilibria of sulfate ions with $\mathrm{HSO}_{4}{ }^{-}$and $\mathrm{H}_{2} \mathrm{SO}_{4}$. Further complications to the precipitation are that peroxide ions can also form complexes with uranyl ions $\mathrm{UO}_{2}\left(\mathrm{O}_{2}\right)_{2}{ }^{2-}$ and $\mathrm{UO}_{2}\left(\mathrm{O}_{2}\right)_{3}{ }^{4-}$.

Low $\mathrm{pH}$ will increase uranyl-ion solubility by keeping the concentration of peroxide ions very low. As the $\mathrm{pH}$ is increased, the free uranyl ion concentration will drop due to an increase in the importance of hydrolysis reactions, complexation with sulfate, and eventually complexation with peroxide ions.

Once the precipitate is filtered/centifuged and washed, the standard procedure is to thermally treat it to form $\mathrm{UO}_{3}$. This thermal process must be carefully performed to minimize reduction to $\mathrm{U}_{3} \mathrm{O}_{8}$, which would be more difficult to dissolve in sulfuric acid (Sheft et al. 1950). The last step is the dissolution of $\mathrm{UO}_{3}$ in sulfuric acid to prepare a solution for recycle. It should also be possible to dissolve the uranyl peroxide in sulfuric acid directly.

The processing steps are as follows:

1. Conditioning the irradiated solution for optimal uranium recovery and purity.

2. Peroxide precipitation.

3. Filtering and washing the precipitate. 
4. Thermal conversion of $\mathrm{UO}_{4}$ to $\mathrm{UO}_{3}$.

5. Dissolution of $\mathrm{UO}_{3}$ in sulfuric acid.

6. Reconstituting the uranyl-sulfate/0.1-M sulfuric acid target solution.

7. Treatment of waste streams generated for storage and final disposal.

Steps 4-6 could be replaced by direct dissolution of the precipitate in sulfuric acid.

Development activities for this option were (1) to find optimized conditions for performing this precipitation and (2) to measure decontamination factors from other irradiatedsolution components. As well as the $\mathrm{pH}$ dependence, conditions for stirring and peroxide addition must be developed that allow formation of a highly crystalline, filterable precipitate. Under typical conditions, the precipitate will resemble a "buttery" precipitate and will be difficult to separate by filtering or centrifugation. Thoroughly washing the precipitate is vital to achieving high decontamination factors for the uranium.

Following this report additional experiments were performed on the uranyl-peroxide precipitation, but we were unable to find conditions that would produce a precipitate that could be successfully filtered or centrifuged on a commercial scale. Therefore, no further experimental work was performed, this option was abandoned, and Argonne only recommends the conversion to nitrate media followed by UREX processing option.

The flowsheet for conversion to nitrate media followed by UREX processing will have 10 processing steps, all of which are commercially viable at the scale required for SHINE target solution cleanup. These steps are as follows:

1. Addition of $\mathrm{Ca}\left(\mathrm{NO}_{3}\right)_{2}$ dissolved in $1-\mathrm{M} \mathrm{HNO}_{3}$ to the irradiated uranyl sulfate solution in a stirred vessel; addition rate and stirring speed are important.

2. Passing the slurry into a filtration system to collect and wash the precipitate (minimize uranium losses).

3. UREX processing of the filtrate.

4. Anion exchange step to remove pertechnetate and iodine from uranium product stream.

5. Precipitation of uranium as ammonium diuranate and its filtration.

6. Conversion of the precipitate to $\mathrm{UO}_{3}$.

7. Dissolution of $\mathrm{UO}_{3}$ in sulfuric acid.

8. Reconstituting the uranyl-sulfate/0.1-M sulfuric acid target solution. 
9. Potential recycle of uranium from ammonium diuranate filtrate.

10. Treatment of waste streams generated for storage and final disposal. design.

This option is the baseline process being integrated into the SHINE pre-conceptual

\section{REFERENCES}

Djogic, R., V. Cucilic, and M. Branica, 2005, "Precipitation of Uranium (VI) Peroxide $\left(\mathrm{UO}_{4}\right)$ in Sodium Perchlorate Solution," Croatica Chemica Acta 78(4): 575-580.

Sheft, I., S. Fried, and N. Davidson, "Preparation of Uranium Trioxide," Journal of the American Chemical Society, 72: 2172-2173. 



\section{Argonne}

Chemical Science and Engineering Division

Argonne National Laboratory

9700 South Cass Avenue, Bldg. 205

Argonne, IL 60439-4837

www.anl.gov 